\title{
Sensory Abilities \\ of Cetaceans
}

Laboratory and

Field Evidence 


\section{NATO ASI Series}

\section{Advanced Science Institutes Series}

A series presenting the results of activities sponsored by the NATO Science Committee, which aims at the dissemination of advanced scientific and technological knowledge, with a view to strengthening links between scientific communities.

The series is published by an international board of publishers in conjunction with the NATO Scientific Affairs Division
A Life Sciences
Plenum Publishing Corporation
B Physics
New York and London
Mathematical
and Physical Sciences
Kluwer Academic Publishers
Behavioral and Social Sciences
Dordrecht, Boston, and London
E Applied Sciences
F Computer and Systems Sciences
G Ecological Sciences
H Cell Biology
Springer-Verlag
Berlin, Heidelberg, New York, London, Paris, and Tokyo

\section{Recent Volumes in this Series}

Volume 190-Control of Metabolic Processes edited by Athel Cornish-Bowden and Maria Luz Cárdenas

Volume 191-Serine Proteases and Their Serpin Inhibitors in the Nervous System:

Regulation in Development and in Degenerative and Malignant Disease edited by Barry W. Festoff

Volume 192-Systems Approaches to Developmental Neurobiology edited by Pamela A. Raymond, Stephen S. Easter, Jr., and Giorgio M. Innocenti

Volume 193-Biomechanical Transport Processes edited by Florentina Mosora, Colin G. Caro, Egon Krause, Holger Schmid-Schönbein, Charles Baquey, and Robert Pelissier

Volume 194-Sensory Transduction edited by Antonio Borsellino, Luigi Cervetto, and Vincent Torre

Volume 195-Experimental Embryology in Aquatic Plants and Animals edited by Hans-Jürg Marthy

Volume 196-Sensory Abilities of Cetaceans: Laboratory and Field Evidence edited by Jeanette A. Thomas and Ronald A. Kastelein

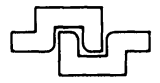

Series A: Life Sciences 


\section{Sensory Abilities of Cetaceans}

Laboratory and Field Evidence

\section{Edited by}

Jeanette A. Thomas

Western Illinois University

Macomb, Illinois

and

Ronald A. Kastelein

Harderwijk Marine Mammal Park

Harderwijk, The Netherlands

Springer Science+Business Media, LLC 
Proceedings of a NATO Advanced Research Workshop and Symposium of the Fifth International Theriological Congress on Sensory Abilities of Cetaceans, held August 22-29, 1989, in Rome, Italy

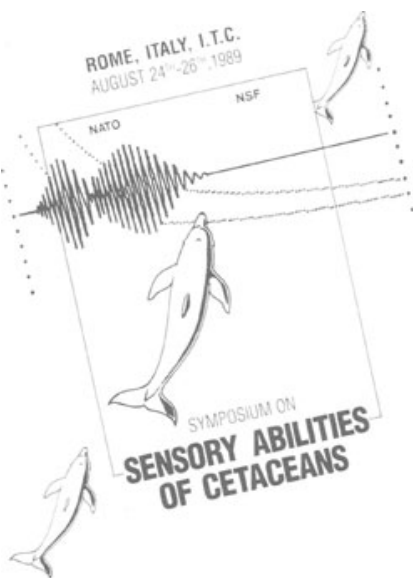

Library of Congress Cataloging-in-Publication Data

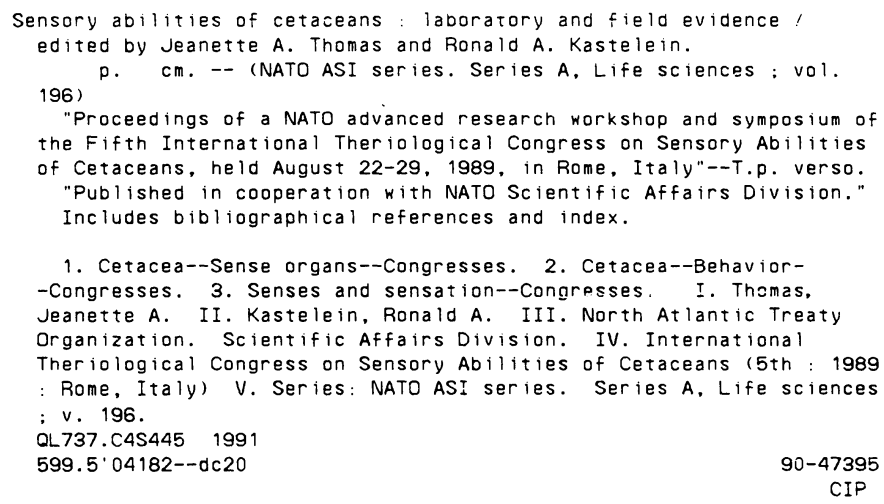

ISBN 978-1-4899-0860-5 ISBN 978-1-4899-0858-2 (eBook)

DOI $10.1007 / 978-1-4899-0858-2$

(C) 1990 Springer Science+Business Media New York

Originally published by Plenum Press, New York in 1990.

Softcover reprint of the hardcover 1st edition 1990

\section{All rights reserved}

No part of this book may be reproduced, stored in a retrieval system, or transmitted in any form or by any means, electronic, mechanical, photocopying, microfilming, recording, or otherwise, without written permission from the Publisher 
To my husband, Victor Ramos, and my children, Julienne and Galen Thomas-Ramos, who provide endless support and encouragement because they realize that my passion for them is only rivaled by my scientific curiosity.

-J.A.T.

To Brigitte Slingerland, for her support during the last two years. I apologize for the many evenings and weekends that I confined myself to my study room. 


\section{PREFACE}

This book evolved through the efforts of several organizations and the dedication of many individuals. In 1987, we received a request to propose a workshop topic for the Fifth International Theriological Congress (ITC) to be held in August 1989 in Rome, Italy. After looking up the meaning of the word "theriological" in the dictionary and discovering that it pertains to mammalian behavior, we decided a symposium on sensory abilities of whales and dolphins would be an interesting topic. The ITC convenes only every five years and has the distinction of being very well attended by scientists from around the world. We thought that hosting a workshop in conjunction with the ITC would attract a variety of international scientists that rarely have the opportunity to interact.

Fortunately for all involved, our prediction was correct. The first two days of the workshop, 23-24 August 1989, were held in conjunction with ITC and the nearly 1,000 attending scientists were able to view our posters and listen to lectures. The third day was limited to only about 65 invited scientists who were divided into topical working groups chaired by a rapporteur.

This book is organized by the working group topics of Sensory Anatomy and Physiology, Acoustic Senses, Vision/Tactition/Chemoreception, Communication, and other senses. The working groups took on very different characters, but each generated a great deal of enthusiasm, promising research ideas, and established a network of colleagues for future collaborations. The success of these working groups is attributed to the rapporteurs: Peter Morgane, Christopher Clark, Frank Awbrey, Karen Pryor, and Herbert Roitblat. The Concluding comments by these rapporteurs in each section of the book gives you a "flavor" of the dynamic exchanges in these groups and the skill of the rapporteurs in stimulating ideas.

Drs. Luigi Boitani and Ernesto Campana, organizers for the 5th ITC, from the University of Rome provided endless advice and logistic support in coordinating our workshop at the ITC. The success of our workshop and this resulting book is due largely to their hard work.

Our workshop was selected as an Advanced Research Workshop (ARW) funded by the Scientific Affairs Division of NATO in Belgium. Dr. Craig Sinclair, the Director for the 
Advanced Study Institutes Programme, encouraged our workshop and gave us a great deal of support. Additional NATO funds were obtained to support the participation of Portuguese scientists through the efforts of $\mathrm{Mr}$. A. Trigo de Abreu.

A large number of US and USSR scientists were able to attend the meeting in Rome because Dr. Herbert Roitblat from the University of Hawaii generously obtained travel funds through a grant from the National science Foundation.

Our colleagues at the Naval Ocean System Center deserve special recognition for the many ways that they contributed to the development of the workshop. We benefited immensely from the advice provided by Paul Nachtigall, Whitlow Au, Patrick Moore, Bill Friedl, and Sam Ridgway based on the experiences they gained when they organized a similar conference. We acknowledge winifred Chrismer for her dedicated and careful work in coordinating the large amount of correspondence related to this workshop and book.

The preparation of this book was funded generously by a NATO publication grant from the Scientific Affairs Division in Belgium.

We thank Ruud de clercq, director of the Harderwijk Marine Mammal Park, for providing the generous logistic support, which largely contributed to the success of the symposium. We also thank him for allowing one of us (RAK) to allocate a large part of his time to the organization of the symposium.

Lastly, we thank Western Illinois University and Harderwijk Marine Mammal Park for their full support in the task of editing the manuscripts in this book. Both organizations provided release time from other duties so that we could edit these papers in a timely manner.

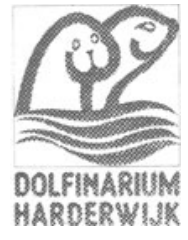

Jeanette A. Thomas Western Illinois University Macomb, Illinois USA

Ronald A. Kastelein Marine Mammal Park Harderwijk, The Netherlands 


\section{SENSORY ANATOMY AND PHYSIOLOGY}

Forehead Anatomy of Phocoena phocoena and Cephalorhynchus commersonii: 3-Dimensional Computer Reconstructions with Emphasis on the Nasal Diverticula . . . . . . Mats Amundin and Ted Cranford

Structure and Thalamocortical Relations of the Cetacean Sensory Cortex: Histological, Tracer and Immunocytochemical Studies . . . . . . .

Laurence J. Garey and Alexander V. Revishchin

A Potential Neural Substrate for Geomagnetic Sensibility

in Cetaceans . . . . . . . . . . . . . Nicholaas M. Gerrits and Ronald A. Kastelein

Immunocytochemistry of Neurotransmitters in Visual

Neocortex of Several Toothed Whales: Light

and Electron Microscopy Study . . . . . . . . . . 39

Ilya I. Glezer, Peter J. Morgane, and Csaba Leranth

Evolution of the Nasal Anatomy of Cetaceans . . . . . 67 John E. Heyning and James G. Mead

Three-dimensional Reconstructions of the Dolphin

Ear . . . . . . . . . .

Darlene R. Ketten and Douglas Wartzok

Sensory Neocortex in Dolphin Brain . . . . . . . 107

Peter J. Morgane and Ilya I. Glezer

Evolutionary Morphology and Acoustics in the

Dolphin Skull

Helmut A. Oelschläger

Tactile Sensitivity, Somatosensory Responses, Skin

Vibrations, and the Skin Surface Ridges of the

Bottlenose Dolphin, Tursiops truncatus .

Sam H. Ridgway and Donald A. Carder

A Potential System of Delay-lines in the Dolphin Auditory

Brainstem

John M. Zook and Ralph A. DiCaprio

Concluding Comments on Sensory Anatomy and Physiology • . 195

Peter J. Morgane 


\section{ACOUSTIC SENSES \\ A. Echolocation/Sound Production}

Target Detection in Noise by Echolocating Dolphins . . 203 Whitlow W. L. Au

Preliminary Notes on Behaviour of a Blindfolded Free-swimming Dolphin Performing a Target Echolocation Task in a Pool Massimo Azzali and Gabriele Buracchi

On the Two Auditory Subsystems in Dolphins . . . . . . 233 Nikolai A. Dubrovskiy

A Proposed Echolocation Receptor for the Bottlenose Dolphin (Tursiops truncatus): Modelling the Receive Directivity from Tooth and Lower Jaw Geometry

A. David Goodson and M. Klinowska

Studies on Echolocation of Porpoises Taken in Salmon

Gillnet Fisheries $\quad$. . . . . . . . . . . . . . 269

Yoshimi Hatakeyama and Hideo Soeda

Very High-frequency Acoustic Emissions from the White-beaked Dolphin (Lagenorhynchus albirostris) . 283 Ronald B. Mitson

High Intensity Narwhal clicks

Bertel M $\phi \mathrm{hl}$, Annemarie Surlykke, and Lee A. Miller

Investigations on the Control of Echolocation Pulses

in the Dolphin (Tursiops truncatus) . . . . . . 305

Patrick W. B. Moore and Deborah A. Pawloski

Purposeful Changes in the Structure of Echolocation

Pulses in Tursiops truncatus . . . . . . . . 317

Evgeniy V. Romanenko

Echolocation Characteristics and Range Detection

Threshold of a False Killer Whale

(Pseudorca crassidens) $\dot{0} \cdot \dot{0} \dot{ }$

Jeanette A. Thomas and Charles W. Turl

\section{B. Hearing}

Preliminary Hearing Study on Gray whales

(Eschrictus robustus) in the Field

Marilyn E. Dahlheim and Donald K. Ljungblad

Inferences about Perception in Large Cetaceans,

Especially Humpback Whales, from Incidental

Catches in Fixed Fishing Gear, Enhancement

of Nets by "Alarm" Devices, and the Acoustics

of Fishing Gear

Jon Lien, Sean Todd, and Jacques Guigne 
Formation of an Adaptive Structure of the Peripheral

Part of the Auditory Analyzer in Aquatic,

Echo-locating Mammals during ontogenesis . . . 363

Galina N. Solntseva

Frequency-selectivity of the Auditory system in the

Bottlenose Dolphin, Tursiops truncatus

Alexander Supin and viadimir Popov

Masked Hearing Abilities in a False Killer Whale

(Pseudorca crassidens)

(Pseudorca crassidens) and Whitlow W. L. Au

Electrophysiological Studies on Hearing in Some

Cetaceans and a Manatee

..

Vladimir Popov and Alexander Supin

Localization of the Acoustic Window at the

Dolphin's Head

Vladimir Popov and Alexander Supin

Concluding Comments on Cetacean Hearing and Echolocation

Frank T. Awbrey

\section{CHEMICAL/TACTILE/VISUAL SENSES}

Preliminary Results from Psychophysical Studies on the Tactile Sensitivity in Marine Mammals . . . . 435 Guido Dehnhardt

Taste Reception in the Pacific Bottlenose Dolphin (Tursiops truncatus gilli) and the California Sea Lion (Zalophus californianus)

William A. Friedl, Paul E. Nachtigall, Patrick W. B. Moore, Norman K. W. Chun, Jeffrey E. Haun, Richard W. Hall, and James L. Richards

Cognitive Performance of Dolphins in Visually-guided Tasks

Louis M. Herman

Anatomical and Histological Characteristics of the Eyes of a Month-old and an Adult Harbor Porpoise (Phocoena) $\cdot$ ·. $\dot{\text { V. J. }}$ Zweypfenning

Ronald A. Kastelein, R
and Henk Spekreijse

Chemical Sense of Dolphins: Quasi-olfaction

vitaly B. Kuznetzov

Best Vision Zones in the Retinae of Some Cetaceans . . 505

Alla Mass and Alexander Supin

Visual Ecology and Cognition in cetaceans

Joseph R. Mobley, Jr. and David A. Helweg 
Non-acoustic Communication in Small Cetaceans: Glance, Touch, Position, Gesture, and Bubbles . . . . . 537 Karen w. Pryor

Visual Displays for Communication in Cetaceans . . . . 545 Bernd würsig, Thomas Kieckhefer, and Thomas A. Jefferson.

Concluding Comments on Vision, Tactition, and Chemoreception . . . . . . . . . . . 561 Karen Pryor

\section{COMMUNICATION}

Acoustic Behavior of Mysticete Whales

Christopher W. Clark

Acoustic Behavior in a Local Population of Bottlenose

Manuel E. dos Santos, Giorgio Caporin,

H. Onofre Moreira, António J. Ferreira, and J. L. Bento Coelho

Organization of Communication System in Tursiops truncatus Montagu . . . . . . . . . 599

Vladimir I. Markov and Vera M. Ostrovskaya

Signalization of the Bottlenose Dolphin during the Adaptation to Different Stressors

Irina E. Sidorova, Vladimir I. Markov, and Vera M. Ostrovskaya

Concluding Comments on Acoustic Communication

Christopher W. Clark

\section{OTHER SENSES}

Geomagnetic Sensitivity in Cetaceans: An Update with Live stranding Records in the United States

Joseph L. Kirschvink

Geomagnetic orientation in Cetaceans: Behavioural Evidence

Margaret Klinowska

Attention and Decision-making in Echolocation Matching-to-Sample by a Bottlenose Dolphin (Tursiops truncatus): The Microstructure of Decision-making . . . . . . . . . . . . . . 665

Herbert L. Roitblat, Ralph A. Penner, and Paul E. Nachtigall

Stimulus Equivalence and Cross-modal Perception: A Testable Model for Demonstrating Symbolic Representations in Bottlenose Dolphins . . . . . 667 Ronald J. Schusterman 
The Ability of Bottlenose Dolphins, Tursiops truncatus,

to Report Arbitrary Information Alexander Zanin, Vladimir I. Markov and Irina E. Sidorova

Concluding Comments on Other Sensory Abilities . . . . 699 Herbert L. Roitblat

INDEX 